\title{
Keragaan Pertumbuhan dan Produksi Aksesi-Aksesi Kacang Tunggak Lokal Asal Maluku
}

\author{
Growth and Yield Performance of Cowpea Accessions from Maluku
}

\author{
Marni Papa ${ }^{1}$, Helen Hetharie ${ }^{2}$, Fransin Polnaya ${ }^{2, *}$ \\ ${ }^{1}$ Program Studi Agroteknologi, Jurusan Budidaya, Fakultas Pertanian, Universitas Pattimura, Jl. Ir. M. Puttuhena, \\ Kampus Poka Ambon, 97233 Indonesia \\ ${ }^{2}$ Jurusan Budidaya Pertanian, Fakultas Pertanian, Universitas Pattimura, J1. I. M. Puttuhena, Kampus Poka Ambon, \\ 97233 Indonesia
}

*E-mail Penulis Korespondensi: fransin.polnaya@faperta.unpatti.ac.id

Tanggal submisi: 18 Oktober 2019; Tanggal penerimaan: 3 Maret 2020

\begin{abstract}
Cowpea belongs to minor legumes that have a prospect for future improvement as a supplementary food source. This research aimed to describe the vegetative growth of local cowpea and obtain genotypes with the highest performances of yield components and yields. This research was conducted as a single factor experiment that tested 14 accessions of cowpea. The study used a Completely Randomized Block Design with three replications. The results showed that KTm-1, KTm-5, KTm-9, KTm-10, KTm-16, and KTm-26 accessions showed a denser appearance characteristic as indicated by their higher branch number and leaf number. Whereas, KTm-12 and KTm-20 had a characteristic of compact canopy appearance with a relatively short plant, but also with greater branch number and leaf number than that of the KT 6 national variety that did not have a dense canopy performance. The performance of KTm-5 and KTm-19 local accessions showed superior appearance in some of the observed yield variables, i.e. total pod number, full pod number, pod weight per plant, seed number, total seed number, and seed weight per plant, compared to the other local accessions. These two former local accessions showed the potential for all yield variables as good as those of the KT6 superior variety. For the seed number per pod and the seed locus number per pod, all local accessions except KTm-1 and KTm-17 were as excellent and high as those of the KT6 superior variety.
\end{abstract}

Keywords: cowpea, local accessions, performance, yield

\section{ABSTRAK}

Kacang tunggak merupakan kacang-kacangan minor yang mempunyai prospek pengembangan ke depan sebagai sumber makanan tambahan. Penelitian bertujuan mendiskripsikan keragaan pertumbuhan vegetatif kacang tunggak lokal dan mendapatkan aksesi kacang tunggak lokal dengan hasil maupun komponen hasil tertinggi. Penelitian ini merupakan percobaan faktor tunggal yaitu menguji 14 aksesi kacang tunggak. Penelitian menggunakan Rancangan Acak Lengkap Berblok dengan tiga ulangan. Hasil penelitian menunjukkan KTm-1, KTm-5, KTm-9, KTm-10, KTm-16 dan KTm-26 memiliki karakteristik penampilan lebih rimbun berdasarkan jumlah cabang dan jumlah daun banyak. Sedangkan KTm-12 dan KTm-20 memiliki karakteristik rimbun dengan ciri tanaman relatif pendek namun jumlah cabang dan jumlah daunnya banyak dibandingkan varietas Nasional KT 6 dengan penampakan yang tidak rimbun. Keragaan produksi aksesi lokal KTm-5 dan KTm-19 memiliki penampilan lebih unggul pada beberapa peubah produksi yang diamati, yaitu jumlah polong total, jumlah polong bernas, bobot polong per tanaman, jumlah biji, jumlah biji bernas, bobot biji per tanaman, dibandingkan aksesi-aksesi lokal yang lain. Dua aksesi lokal tersebut berpotensi pada semua peubah produksi yang sama baik dengan varietas unggul KT6. Pada peubah jumlah biji per polong dan jumlah lokus biji per polong semua aksesi lokal sama baik dan tinggi dengan varietas unggul KT6 kecuali aksesi lokal KTm-1 dan KTm-17.

Kata kunci: aksesi lokal, kacang tunggak, keragaan, produksi 


\section{PENDAHULUAN}

Kacang tunggak (Vigna unguiculata L. Walp.) merupakan salah satu kacang-kacangan minor yang mempunyai prospek pengembangan ke depan sebagai pangan, pakan, industri, kesehatan, bahkan sebagai pupuk hijau. Perkembangan saat ini, biji kering kacang tunggak telah dijadikan sebagai alternatif bahan baku dalam pembuatan tempe dan tahu (Haliza, 2008; Haliza et al., 2007). Keunggulan kacang tunggak yaitu memiliki kadar lemak yang rendah (Rosida, 2013). Berdasarkan komposisi kimia utama yang ada didalamnya, kacang tunggak sesuai untuk bahan baku pembuatan tempe (BB pascapanen, 2008). Sumber daya genetik kacang tunggak lokal yang terdapat di beberapa daerah di Indonesia termasuk Maluku perlu mendapat perhatian dalam penelitian untuk memproduksi biji kering maupun aneka sayuran. Di Indonesia, tanaman kacang tunggak sudah lama dikenal dan ditanam oleh petani, namun pengembangannya belum secara meluas. Menurut Hetharie et al. (2009) budidaya kacang tunggak varietas lokal asal Kabupaten Maluku Tenggara Barat (MTB) dilakukan secara tradisional, tidak intensif, dan tergantung dari alam.

Penelitian ini dilakukan terhadap beberapa aksesi kacang tunggak lokal maupun varietas unggul sebagai pembandingnya. Kabupaten Maluku Tenggara Barat (MTB) dan Maluku Barat Daya (MBD) merupakan dua kabupaten di Propinsi Maluku, yang memiliki kekayaan plasma nutfah yang tinggi. Evaluasi sifat -sifat penting yang berkaitan dengan produksi kacang tunggak asal kabupaten MTB dan MBD dilakukan untuk manfaat sebagai sumber pangan dan suatu sumber gen dalam program pemuliaan tanaman.

Di Indonesia produksi kacang tunggak cukup tinggi yaitu mencapai 494.506 ton (BPS, 2012). Tergantung varietas, lokasi, musim tanam dan budidaya yang diterapkan (Sayekti et al., 2012). Kacang tunggak merupakan salah satu kacang lokal yang memiliki potensi untuk dikembangkan, maka diperlukan tindakan budidaya yang tepat agar produksi kacang tunggak ditingkatkan. Salah satu tindakkan budidaya tanaman kacang tunggak yang dapat meningkatkan pertumbuhan dan produktivitasnya adalah dengan penggunaan lanjaran. Umumnya kacang tunggak ditanam tidak menggunakan lanjaran, namun dalam penelitian ini sudah dilakukan di lahan dengan teknologi budidaya menggunakan lanjaran. Untuk mengetahui produktivitas dari aksesi -aksesi kacang tunggak lokal asal MTB dan MBD serta varietas pembanding KT6, karena belum diketahui hasil maupun komponen hasilnya.

Budidaya tanaman kacang tunggak dengan tidak mengunakan lanjaran, pada kacang tunggak varietas unggul KT6 yaitu 2,037 ton/ha didukung jumlah biji per tanaman sebanyak 86,13 biji (Sayekti et al., 2012). Penelitian dengan menggunakan lanjaran skala pot pada rumah kaca terhadap beberapa kacang tunggak lokal memperlihatkan keragaan KTm-16 menunjukkan komponen produksi relatif lebih tinggi melalui peubah jumlah polong per tanaman, dan berat 100 biji secara berturut 42,78 polong dan $26,58 \mathrm{~g}$. Sedangkan varietas unggul KT6 pada peubah jumlah polong per tanaman, dan berat 100 biji secara berturut 35,44 polong dan 15,39 g (Hetharie et al., 2015). Hasil penelitian di lahan tanpa lanjaran terhadap beberapa aksesi kacang tunggak, menunjukkan KTm-10 asal MTB berpotensi dengan produksi tertinggi melalui jumlah polong per tanaman, berat biji per polong, berat 100 biji, dan berat 1000 biji per petak secara berturut: 32 polong, 3,0 g, 19,83 g, dan 195,05 g, (Hetharie et al., 2013). Hasil ini menunjukkan bahwa aksesi-aksesi lokal mempunyai potensi produksi lebih tinggi dibandingkan dengan varietas unggul KT6 (Hetharie et al., 2015).

Heritabilitas merupakan pengaruh keragaman genetik terhadap fenotipe dalam suatu populasi. Karakterisasi secara morfologis memperlihatkan populasi bahan genetik kacang tunggak memiliki keragaman dan kemiripan sifat kualitatif maupun kuantitatif (Trustinah 2013). Syukur et al. (2011) mengemukakan bahwa seleksi akan efektif jika populasi mempunyai keragaman genetik yang luas dan heritabilitas yang tinggi, sehingga hal tersebut sangat bermanfaat dalam proses seleksi. Menurut Umaharan et al. (1997), makin besar nilai duga heritabilitas, makin tinggi pengaruh faktor genetik. Sebaliknya, makin rendah nilai heritabilitas, makin besar pengaruh faktor lingkungan. Diharapkan pada penelitian ini didapatkan aksesi-aksesi lokal yang mempunyai hasil dan komponen hasil tertinggi dilahan ketika menggunakan lanjaran. Tujuan dari penelitian ini untuk mendiskripsikan keragaan pertumbuhan vegetatif kacang tunggak lokal dan mendapatkan aksesi-aksesi kacang tunggak lokal yang menunjukkan hasil maupun komponen hasil tertinggi serta menduga karakter-karakter yang dipengaruhi oleh faktor genetik dan faktor lingkungan.

\section{METODE PENELITIAN}

Penelitian dilakukan di lahan Lembaga Penelitian Universitas Pattimura, Desa Rumah Tiga. Penelitian ini merupakan penelitian satu faktor menggunakan rancangan acak lengkap berblok dengan pengulangan tiga kali. Faktor yang dicobakan adalah 13 aksesi kacang tunggak lokal yang berasal dari MTB dan Maluku Barat Daya (MBD) serta 1 varietas Nasional. Terdapat 42 satuan percobaan yang masing-masing terdiri dari 16 tanaman per petak dan tiap petak terdiri dari 4 tanaman sampel. pembuatan petak dengan ukuran $1,6 \mathrm{~m} \times 0,8 \times 0,3 \mathrm{~m}$, jarak antar petak $50 \mathrm{~cm}$, jarak antara blok $2 \mathrm{~m}$ dan ukuran lahan percobaan $275,79 \mathrm{~m}^{2}$. jarak tanam yaitu: $40 \mathrm{~cm} \times 20 \mathrm{~cm}$, Jumlah benih perlubang 2 benih dan pemasangan lanjaran dilakukan 1 minggu setelah tanam. dosis pupuk kandang yang digunakan 3,2 $\mathrm{kg}$ perpetak atau $200 \mathrm{~g}$ per tanaman. Pemupukkan anorganik dilakukan pada umur $20 \mathrm{hst}$, dosis pupuk Urea dan TSP yang digunakan 12,8 g per petak atau 4,3 g perlarikan tanaman, sedangkan pupuk $\mathrm{KCl} 10,24 \mathrm{~g}$ perpetak atau 3,41 g perlarikan tanaman. peubah yang terukur yaitu tinggi tanaman, jumlah cabang, jumlah daun pada umur 12 minggu setelah 
tanam. Sedangkan jumlah polong, panjang polong, jumlah biji, jumlah polong bernas, jumlah biji bernas, jumlah biji per polong, jumlah lokus biji per polong, bobot polong per tanaman dan bobot biji per tanaman setelah panen. Semua peubah di analisis ragam, dan peubah yang menunjukkan perbedaan nyata atau sangat nyata dilanjutkan dengan uji jarak berganda Duncan.

\section{HASIL DAN PEMBAHASAN}

\section{Keragaan Vegetatif Tanaman Kacang Tunggak}

Berdasarkan hasil uji ragam ada perbedaan antara aksesi kacang tunggak pada semua peubah vegetatif meliputi tinggi tanaman, jumlah cabang dan jumlah daun. Selanjutnya dilakukan uji beda untuk mengetahui keragaan dari setiap aksesi tersebut. Berdasarkan hasil uji beda aksesi lokal KTm-9 menunjukkan keragaan tanaman lebih tinggi, jumlah daun dan jumlah cabang terbanyak. Aksesi lokal KTm-1, KTm-5, KTm-10, KTm-16 dan KTm-26 mempunyai keragaan tanaman yang juga tinggi tetapi masih lebih rendah dari KTm-9. Aksesi-aksesi lokal yang diuji menunjukkan lebih beragam antara aksesi pada tinggi tanaman dibandingkan jumlah daun dan jumlah cabang. Perbedaan keragaan dari aksesi-aksesi tersebut menunjukkan adanya pengaruh genetik ataupun lingkungan. Menurut Crowder (2006) kenampakan suatu fenotipe tergantung dari sifat varietas dan hubungan antara genotipe dengan lingkungan.

Berdasarkan tiga peubah vegetatif yang diuji, aksesi lokal yang menunjukkan keragaan tanaman yang rimbun dengan ciri tanaman relatif pendek dibandingkan aksesi lokal lainnya, namun jumlah cabang dan jumlah daun banyak yaitu KTm-12, KTm-17 dan KTm-20. Sedangkan Varietas unggul KT6 menunjukkan keragaan yang tidak rimbun dengan ciri ukuran tanaman terpendek namun jumlah daun dan jumlah cabang yang relatif sedikit. Aksesi-aksesi lokal memiliki keragaan vegetatif lebih tinggi jika dibandingkan varietas unggul KT6. Hasil ini menunjukkan bahwa semakin tinggi tanaman memungkinkan untuk semakin banyak cabang yang terbentuk dan berdampak pada jumlah daun serta pertumbuhan. Apabila jumlah cabang bertambah maka jumlah bunga yang terbentuk juga akan bertambah sehingga banyak polong yang dihasilkan. Menurut Marsita (2012) semakin tinggi tanaman maka pembentukan cabang semakin banyak.

\section{Keragaan Produksi Tanaman Kacang Tunggak}

Penampilan produksi dari aksesi-aksesi lokal menunjukkan adanya keragaman antara aksesi, hal ini didasarkan pada hasil uji ragam yang diperoleh nyata sampai sangat nyata. Beberapa karakter tersebut adalah jumlah biji per polong, jumlah lokus biji per polong dan jumlah biji bernas per tanaman yang berpengaruh nyata. Karakter jumlah polong per tanaman, jumlah polong bernas per tanaman, jumlah biji per tanaman, bobot polong per tanaman dan bobot biji per tanaman memiliki pengaruh sangat nyata. Berdasarkan hasil uji beda diperoleh aksesi lokal KTm-5 dan KTm-19 yang merupakan varietas dengan jumlah polong per tanaman, jumlah polong bernas per tanaman dan bobot polong per tanaman tertinggi yaitu 26 polong, 31 polong, 26 polong, 29 polong, dan 52,36 g, 53,17 g dan juga varietas unggul KT6 yaitu 33 polong, 33 polong, 64,23 g dibandingkan aksesi lokal KTm-1, KTm-8, KTm-17 dan KTm-20 dengan produksi terendah. Hasil ini sama dengan penelitian dari Patty (2012) yang menjelaskan bahwa KTm-5 memiliki jumlah polong bernas per tanaman tertinggi yaitu 18 polong yang sama baiknya dengan KT6 yaitu 19 polong. Hasil ini menunjukkan bahwa aksesi lokal memiliki keragaan produksi yang tinggi dibandingkan dengan KT6, ini disebabkan karena adanya faktor genetik dan lingkungan yang mempengaruhi hasil produksi.

Tabel 1. Hasil uji beda rataan untuk peubah tinggi tanaman, jumlah cabang dan jumlah daun

\begin{tabular}{lccc}
\hline \multicolumn{1}{c}{ Varietas } & Tinggi tanaman $(\mathrm{cm})$ & Jumlah cabang & Jumlah daun \\
\hline KTm-1 & $510,67 \mathrm{bcd}$ & $9,00 \mathrm{a}$ & $75,33 \mathrm{a}$ \\
KTm-5 & $539,17 \mathrm{~b}$ & $7,17 \mathrm{ab}$ & $60,83 \mathrm{ab}$ \\
KTm-6 & $478,33 \mathrm{cdef}$ & $7,00 \mathrm{ab}$ & $69,50 \mathrm{a}$ \\
KTm-8 & $474,83 \mathrm{defg}$ & $6,67 \mathrm{~b}$ & $64,33 \mathrm{a}$ \\
KTm-9 & $621,17 \mathrm{a}$ & $8,33 \mathrm{ab}$ & $78,50 \mathrm{a}$ \\
KTm-10 & $522,00 \mathrm{bc}$ & $8,83 \mathrm{a}$ & $71,67 \mathrm{a}$ \\
KTm-12 & $451,00 \mathrm{fg}$ & $9,00 \mathrm{a}$ & $80,50 \mathrm{a}$ \\
KTm-13 & $436,00 \mathrm{~g}$ & $6,50 \mathrm{bc}$ & $58,33 \mathrm{ab}$ \\
KTm-16 & $502,50 \mathrm{bcde}$ & $8,83 \mathrm{a}$ & $78,83 \mathrm{a}$ \\
KTm-17 & $467,17 \mathrm{defg}$ & $7,50 \mathrm{ab}$ & $72,00 \mathrm{a}$ \\
KTm-19 & $486,67 \mathrm{cdef}$ & $8,50 \mathrm{ab}$ & $60,17 \mathrm{ab}$ \\
KTm-20 & $459,17 \mathrm{efg}$ & $8,00 \mathrm{ab}$ & $77,50 \mathrm{a}$ \\
KTm-26 & $537,00 \mathrm{~b}$ & $7,00 \mathrm{ab}$ & $67,83 \mathrm{a}$ \\
KT6 & $334,67 \mathrm{~h}$ & $4,67 \mathrm{c}$ & $40,33 \mathrm{~b}$ \\
\hline KK & $4,90 \%$ & $14,45 \%$ & $18,22 \%$ \\
\hline
\end{tabular}

Keterangan: Angka-angka dalam kolom yang di ikuti oleh huruf yang sama tidak berbeda nyata pada taraf $5 \%$, dan data di atas adalah data asli. 
Tabel 2. Hasil rataan uji beda pada komponen hasil jumlah polong per tanaman, jumlah polong bernas per tanaman, dan bobot polong per tanaman

\begin{tabular}{lccc}
\hline \multicolumn{1}{c}{ Varietas } & Jumlah polong per tanaman & $\begin{array}{c}\text { Jumlah polong bernas per } \\
\text { tanaman }\end{array}$ & Bobot polong per tanaman $(\mathrm{g})$ \\
\hline KTm-1 & $1,78(2,83) \mathrm{c}$ & $1,78(2,83) \mathrm{c}$ & $2,45(5,62) \mathrm{de}$ \\
KTm-5 & $5,15(26,83) \mathrm{ab}$ & $5,13(26,83) \mathrm{ab}$ & $7,18(52,36) \mathrm{a}$ \\
KTm-6 & $2,52(6,00) \mathrm{c}$ & $2,52(6,00) \mathrm{c}$ & $3,37(10,97) \mathrm{cde}$ \\
KTm-8 & $1,90(3,17) \mathrm{c}$ & $1,90(3,17) \mathrm{c}$ & $2,83(7,60) \mathrm{de}$ \\
KTm-9 & $2,58(6,33) \mathrm{c}$ & $2,58(6,33) \mathrm{c}$ & $3,48(12,12) \mathrm{cde}$ \\
KTm-10 & $2,49(5,83) \mathrm{c}$ & $2,47(5,83) \mathrm{c}$ & $3,72(13,48) \mathrm{cd}$ \\
KTm-12 & $2,19(4,50) \mathrm{c}$ & $2,09(4,00) \mathrm{c}$ & $3,03(9,15) \mathrm{cde}$ \\
KTm-13 & $4,44(19,50) \mathrm{b}$ & $4,39(19,00) \mathrm{b}$ & $5,81(33,76) \mathrm{b}$ \\
KTm-16 & $2,69(7,00) \mathrm{c}$ & $2,67(6,83) \mathrm{c}$ & $3,53(12,21) \mathrm{cde}$ \\
KTm-17 & $1,43(1,67) \mathrm{c}$ & $1,43(1,67) \mathrm{c}$ & $2,08(4,07) \mathrm{e}$ \\
KTm-19 & $5,55(31,00) \mathrm{ab}$ & $5,39(29,00) \mathrm{ab}$ & $7,27(53,17) \mathrm{a}$ \\
KTm-20 & $1,82(2,83) \mathrm{c}$ & $1,61(2,17) \mathrm{c}$ & $2,75(7,06) \mathrm{de}$ \\
KTm-26 & $2,56(6,17) \mathrm{c}$ & $2,51(5,83) \mathrm{c}$ & $4,45(19,44) \mathrm{c}$ \\
KT6 & $5,75(33,33) \mathrm{a}$ & $5,73(33,17) \mathrm{a}$ & $8,01(64,23) \mathrm{a}$ \\
\hline KK & $21,87 \%$ & $21,35 \%$ & $17,71 \%$ \\
\hline
\end{tabular}

Keterangan: Data dalam kurung adalah data asli sedangkan data diluar kurung adalah data transformasi square root yang di pakai untuk uji F dan uji Duncan. Angka-angka yang ditandai dengan huruf yang sama pada kolom yang sama, tidak berbeda nyata pada taraf $5 \%$.

Tabel 3. Hasil rataan uji beda pada komponen hasil jumlah biji per tanaman, jumlah biji bernas pertanaman, dan bobot biji per tanaman

\begin{tabular}{lccc}
\hline \multicolumn{1}{c}{ Varietas } & Jumlah biji per tanaman & $\begin{array}{c}\text { Jumlah biji bernas per } \\
\text { tanaman }\end{array}$ & Bobot biji per tanaman $(\mathrm{g})$ \\
\hline KTm-1 & $5,63(32,33) \mathrm{cd}$ & $4,02(16,25) \mathrm{cd}$ & $2,19(4,51) \mathrm{ef}$ \\
KTm-5 & $18,74(358,83) \mathrm{a}$ & $5,84(33,67) \mathrm{a}$ & $6,12(37,70) \mathrm{ab}$ \\
KTm-6 & $8,20(68,17) \mathrm{c}$ & $5,21(26,67) \mathrm{abc}$ & $3,14(9,45) \mathrm{cde}$ \\
KTm-8 & $6,64(44,33) \mathrm{cd}$ & $4,94(25,00) \mathrm{abc}$ & $2,42(5,46) \mathrm{def}$ \\
KTm-9 & $8,50(72,67) \mathrm{c}$ & $5,28(27,50) \mathrm{abc}$ & $3,16(9,62) \mathrm{cde}$ \\
KTm-10 & $8,55(73,67) \mathrm{c}$ & $5,53(30,08) \mathrm{ab}$ & $3,12(9,26) \mathrm{cde}$ \\
KTm-12 & $6,91(51,50) \mathrm{cd}$ & $4,71(22,25) \mathrm{abc}$ & $2,48(6,23) \mathrm{def}$ \\
KTm-13 & $15,29(235,50) \mathrm{b}$ & $5,06(25,25) \mathrm{abc}$ & $5,22(27,02) \mathrm{b}$ \\
KTm-16 & $9,50(91,00) \mathrm{c}$ & $5,68(31,75) \mathrm{a}$ & $3,32(10,73) \mathrm{cd}$ \\
KTm-17 & $4,38(21,33) \mathrm{d}$ & $3,14(11,00) \mathrm{d}$ & $1,87(3,38) \mathrm{f}$ \\
KTm-19 & $20,33(419,00) \mathrm{a}$ & $5,86(33,92) \mathrm{a}$ & $6,53(42,30) \mathrm{a}$ \\
KTm-20 & $6,33(39,83) \mathrm{cd}$ & $4,28(17,92) \mathrm{bcd}$ & $2,44(5,45) \mathrm{def}$ \\
KTm-26 & $8,90(79,50) \mathrm{c}$ & $5,65(31,50) \mathrm{a}$ & $3,80(14,00) \mathrm{c}$ \\
KT6 & $19,81(396,83) \mathrm{a}$ & $6,04(36,08) \mathrm{a}$ & $7,06(49,46) \mathrm{a}$ \\
\hline KK & $19,06 \%$ & $13,56 \%$ & $15,39 \%$ \\
\hline
\end{tabular}

Keterangan: Data dalam kurung adalah data asli sedangkan data diluar kurung adalah data transformasi square root yang di pakai untuk uji F dan uji Duncan. Angka-angka yang ditandai dengan huruf yang sama pada kolom yang sama, tidak berbeda nyata pada taraf $5 \%$.

Karakter kacang tunggak yang menunjukkan penampilan produksi pada aksesi lokal KTm-5, dan KTm-19 memiliki jumlah biji per tanaman, jumlah biji bernas per tanaman dan bobot biji per tanaman tertinggi yaitu (358 biji dan 419 biji), (33 biji dan 33 biji) serta (37,70 g dan 42,30 g) yang diikuti oleh KTm-13 yaitu (235 biji, 25 biji, dan 27,02 g) juga varietas unggul KT6 yaitu (396 biji, 36 biji dan 49,46 g). Dibandingkan aksesi lokal KTm-1, KTm-12, KTm-17 dan KTm-20 dengan produksi terendah. Hasil penelitian ini menunjukkan bahwa jumlah cabang dan jumlah daun yang banyak tidak mempengaruhi hasil produksinya juga tinggi. Aksesi lokal memiliki potensi produksi yang tinggi tetapi tidak lebih tinggi dari KT6 apabila dibandingkan dengan penelitian yang lain pada aksesi yang sama dengan varietas pembandingnya. Aksesi lokal masih dapat mempertahankan produksi tertinggi dibandingan varietas unggul KT6. Hal ini menunjukkan bahwa aksesi-aksesi lokal mempunyai potensi produksi lebih tinggi dibandingkan dengan varietas unggul KT6 (Hetharie et al., 2015). Marsita (2012) menyatakan bahwa KTm-5 memiliki jumlah biji per tanaman dan bobot biji per tanaman tertinggi yaitu 235 biji dan 34,5 g. Pada KT6 menunjukkan jumlah biji per tanaman dan bobot biji per tanaman terendah yaitu 144 biji dan 25,7 g. 
Tabel 4. Hasil rataan uji beda pada komponen hasil jumlah biji per polong dan jumlah lokus biji per polong

\begin{tabular}{lcc}
\hline \multicolumn{1}{c}{ Varietas } & Jumlah biji per polong & Jumlah lokus biji per polong \\
\hline KTm-1 & $3,27(10,40) \mathrm{c}$ & $3,33(10,87) \mathrm{cd}$ \\
KTm-5 & $4,18(17,00) \mathrm{a}$ & $4,18(17,00) \mathrm{ab}$ \\
KTm-6 & $3,72(13,40) \mathrm{ab}$ & $3,88(14,60) \mathrm{abc}$ \\
KTm-8 & $3,77(13,73) \mathrm{ab}$ & $3,80(14,00) \mathrm{abc}$ \\
KTm-9 & $3,91(14,80) \mathrm{ab}$ & $4,07(16,07) \mathrm{ab}$ \\
KTm-10 & $3,72(13,40) \mathrm{ab}$ & $3,84(14,27) \mathrm{abc}$ \\
KTm-12 & $3,58(12,33) \mathrm{ab}$ & $3,73(13,47) \mathrm{abc}$ \\
KTm-13 & $3,95(15,20) \mathrm{a}$ & $4,03(15,73) \mathrm{ab}$ \\
KTm-16 & $3,99(15,40) \mathrm{a}$ & $4,12(16,47) \mathrm{ab}$ \\
KTm-17 & $2,86(8,40) \mathrm{c}$ & $2,96(8,93) \mathrm{d}$ \\
KTm-19 & $4,06(16,00) \mathrm{a}$ & $4,14(16,67) \mathrm{ab}$ \\
KTm-20 & $3,63(12,73) \mathrm{ab}$ & $3,68(13,07) \mathrm{bc}$ \\
KTm-26 & $3,82(14,13) \mathrm{ab}$ & $3,87(14,47) \mathrm{abc}$ \\
KT6 & $4,19(17,07) \mathrm{a}$ & $4,34(18,33) \mathrm{a}$ \\
\hline KK & $9,20 \%$ & $8,44 \%$ \\
\hline
\end{tabular}

Keterangan: Data dalam kurung adalah data asli sedangkan data diluar kurung adalah data transformasi square root yang di pakai untuk uji F dan uji Duncan. Angka-angka yang ditandai dengan huruf yang sama pada kolom yang sama, tidakberbeda nyata pada taraf $5 \%$.

Hasil uji beda peubah produksi menunjukkan sebagian besar aksesi lokal memiliki jumlah biji per polong dan jumlah lokus biji per polong terbanyak, yang tidak berbeda dengan varietas unggul KT6. Sedangkan KTm-1 dan KTm-17 memiliki jumlah biji per polong dan jumlah lokus biji per polong terendah. Hasil ini menunjukkan bahwa terdapat aksesi lokal yang memiliki jumlah lokus biji per polong dengan jumlah banyak, ternyata tidak mempengaruhi jumlah biji yang terbentuk pada polong. Hasil ini berbeda dengan penelitian Afitu et al. (2016) menunjukkan bahwa semakin banyak lokus per polong pada suatu aksesi maka akan berpotensi menghasilkan jumlah biji per tanaman yang banyak sehingga berdampak pada hasil (berat biji (g) pertanman). Faktor ukuran biji ikut mempengaruhi jumlah lokus biji dan jumlah biji yang terbentuk dalam tiap lokus tersebut, sehingga berpotensi pada hasil biji (bobot biji). Ogle et al. (1987) mengklasifikasi varietas kacang tunggak berdasarkan berat 100 biji. Varietas dengan berat biji 10-15 g dikelompokkan sebagai berukuran kecil, berat biji 15,1$20 \mathrm{~g}$ berukuran sedang, dan ukuran biji besar mempunyai berat 20,1-25 g. Hasil penelitian Hetharie et al. (2015) menunjukkan bahwa aksesi KTm-16 memiliki jumlah biji seluruhnya per polong tertinggi yaitu 12 biji yang sama baiknya dengan KT6 yaitu 13 biji. Hasil ini berbeda dari penelitian yang dilakukan, karena aksesi lokal masih memiliki potensi jumlah biji per polong yang lebih banyak.

\section{Heritabiitas}

Heritabilitas merupakan suatu petunjuk seberapa besar suatu karakter atau sifat dipengaruhi oleh faktor genetik dan faktor lingkungan. Nilai heritabilitas yang tinggi menunjukkan faktor genetik lebih berperan dalam mengendalikan suatu sifat dibandingkan faktor lingkungan. Hal ini bermanfaat untuk menentukan metode seleksi yang tepat, Sehingga dapat ditunjukkan dari karakter-karakter dengan peubah yang dicobakan pada (Tabel 5).

Hasil uji Heritabilitas tanaman terhadap peubah vegetatif dan peubah produksi, menunjukkan nilai heritabilitas yang tinggi. Pada peubah vegetatif yaitu tinggi tanaman sedangkan pada peubah produksi yaitu jumlah polong per tanaman, jumlah polong bernas per tanaman, jumlah biji per tanaman, jumlah biji bernas per tanaman, bobot polong per tanaman dan bobot biji per tanaman. Berdasarkan hasil uji heritabilitas, menunjukkan bahwa penampilan peubah-peubah yang diamati dipengaruhi oleh faktor genetik. Maka kegiatan seleksi untuk perbaikan sifat-sifat tersebut relatif mudah dilakukan. Hasil penelitian Ujianto et al. (2012) bahwa tinggi tanaman menunjukkan nilai duga heritabilitas yang tinggi. Sifat ini sangat dipengaruhi oleh faktor genetik, kurang dipengaruhi oleh faktor lingkungan. Demikian juga menurut Rao et al. (2006), jumlah polong per tanaman memiliki nilai duga heritabilitas yang tinggi dan secara langsung berpengaruh terhadap hasil. Sehingga untuk perbaikan hasil, karakter jumlah polong dapat digunakan sebagai kriteria seleksi. Hal ini didukung oleh pendapat Martono (2009), sifat yang memiliki nilai heritabilitas tinggi menunjukkan bahwa penampilannya lebih ditentukan oleh faktor genetik sehingga seleksi pada sifat tersebut efisien dan efektif karena akan memberikan harapan kemajuan genetik yang besar.

Berdasarkan hasil penelitian, uji heritabilitas menunjukkan bahwa peubah vegetatif dan produksi juga memiliki nilai heritabilitas kriteria sedang. Pada peubah vegetatif yaitu jumlah daun dan jumlah cabang, sedangkan pada peubah produksi yaitu panjang polong, jumlah biji per polong dan jumlah lokus biji per polong. 
Tabel 5. Pendugaan heritabilitas pada peubah vegetatif dan produksi

\begin{tabular}{lcccc}
\hline \multicolumn{1}{c}{ Karakter } & $\sigma^{2} \mathrm{~g}$ & $\sigma^{2} \mathrm{p}$ & Heritabilitas & $\begin{array}{c}\text { Kriteria } \\
\text { heritabilitas }\end{array}$ \\
\hline Tinggi tanaman & 3944,17 & 4513,37 & 0,87 & Tinggi \\
Jumlah cabang & 1,14 & 2,36 & 0,48 & Sedang \\
Jumlah daun & 67,21 & 221,83 & 0,30 & Sedang \\
jumlah polong per tanaman & 2,07 & 2,52 & 0,82 & Tinggi \\
panjang polong per tanaman & 0,08 & 0,38 & 0,23 & Sedang \\
jumlah biji per polong & 0,09 & 0,21 & 0,42 & Sedang \\
jumlah lokus biji per polong & 0,09 & 0,20 & 0,45 & Sedang \\
jumlah biji bernas per tanaman & 0,51 & 0,99 & 0,52 & Tinggi \\
jumlah polong bernas per tanaman & 2,06 & 2,48 & 0,83 & Tinggi \\
bobot polong per tanaman & 3,67 & 4,25 & 0,86 & Tinggi \\
jumlah biji per tanaman & 29,20 & 33,24 & 0,88 & Tinggi \\
bobot biji per tanaman & 2,87 & 3,21 & 0,89 & Tinggi \\
\hline
\end{tabular}

Keterangan: $\sigma \mathrm{g}^{2}=$ Ragam genotipe, $\sigma \mathrm{p}^{2}=$ Ragam fenotipe

Sifat-sifat tersebut sama dipengaruhi oleh faktor genetik dan lingkungan. Nilai heritabilitas yang masuk kategori sedang menunjukkan bahwa pengaruh faktor lingkungan sama besarnya dengan pengaruh faktor genetik. Hasil penelitian Ninik ddk. (2016) menyatakan bahwa nilai heritabilitas sedang, ditunjukkan oleh sifat jumlah cabang produktif per tanaman dan panjang polong secara berturut-turut 0,36 dan 0,33 pada tanaman kacang tunggak.

\section{KESIMPULAN}

Berdasarkan hasil penelitian maka dapat disimpulkan hal-hal sebagai berikut:

1. Aksesi kacang tunggak lokal KTm-1, KTm-5, KTm9, KTm-10, KTm-16 dan KTm-26 memiliki karakteristik penampilan lebih rimbun melalui jumlah cabang dan jumlah daun banyak. Sedangkan aksesi lokal KTm-12 dan KTm-20 memiliki karakteristik rimbun dengan ciri tanaman relatif pendek namun jumlah cabang dan jumlah daun banyak dari pada varietas Nasional KT 6 dengan keragaan yang tidak rimbun.

2. Keragaan produksi aksesi lokal KTm-5 dan KTm-19 memiliki penampilan lebih unggul pada beberapa peubah produksi yang diamati yaitu jumlah polong, jumlah polong bernas, bobot polong per tanaman, jumlah biji, jumlah biji bernas, bobot biji per tanaman dibandingkan aksesi lokal yang lain. Dua aksesi lokal ini berpotensi pada semua peubah produksi sama baik dengan varietas unggul KT6. Pada peubah jumlah biji per polong dan jumlah lokus biji per polong semua aksesi lokal sama baik dan tinggi dengan varietas unggul KT6 kecuali aksesi lokal KTm-1 dan KTm-17.

3. Karakter vegetatif yakni tinggi tanaman dan produksi yakni jumlah polong per tanaman, jumlah polong bernas per tanaman, jumlah biji per tanaman, jumlah biji bernas per tanaman, bobot polong per tanaman dan bobot biji per tanaman dari aksesi lokal memiliki nilai heritabilitas tinggi yang sangat dipengaruhi oleh faktor genetik.

\section{DAFTAR PUSTAKA}

Afitu, G.K., H. Hetharie, dan E. Jambormias. 2016. Keragaan pertumbuhan dan produksi beberapa aksesi kacang tunggak lokal (Vigna ungiculata (L) Walp.) di Desa Waitidal Kabupaten Maluku Tenggara Barat. Jurnal Budidaya Pertanian 12: 20-24.

BB Pascapanen. 2008. Alternatif Kacang-kacangan untuk Tahu dan Tempe. Info Aktual 2 Juni 2008. Kementerian Pertanian Badan Litbang Pertanian. http://www.litbang.deptan.go.id/berita/one/597

Badan Pusat Statistik. 2012. Produksi Tanaman Pangan. Jakarta.

Crowder, L.V. 2006. Genetika Tumbuhan. Yogyakarta: Gadjah Mada University Press.

Haliza, W. 2008. Tanpa kedelai tetap bisa makan tempe. Warta Penelitian dan Pengembangan Pertanian 30: 10-12.

Haliza, W., E.Y. Purwani, dan R. Thahir. 2007. Pemanfaatan kacang-kacangan lokal sebagai substitusi bahan baku tempe dan tahu. Buletin Teknologi Pasca panen Pertanian 3: 18.

Hetharie, H., S.H.T. Raharjo, J.D. Siwalete, dan M.L. Hehanusa. 2009. Eksplorasi Karakterisasi Potensi Genetik Plasma Nutfah KacangKacangan Minor di Kabupaten Maluku Tenggara Barat. Laporan Penelitian Hibah Kompetitif Penelitian Sesuai Prioritas Nasional Batch III. T.A. 2009.

Hetharie, H., M.L. Hehanussa, dan S.H.T. Raharjo. 2013. Potensi produksi beberapa aksesi kacang tunggak lokal [Vigna unguiculata (L) Walp]. Jurnal Budidaya Pertanian 9: 22-25.

Hetharie, H., S.H.T. Raharjo, dan I.J. Lawalata. 2015. Respons beberapa aksesi kacang tunggak local terhadap perlakuan pupuk organik cair. Jurnal Budidaya Pertanian 11: 7-11. 
Marsita, 2012. Keragaan Pertumbuhan dan Produksi Beberapa Aksesi Kacang Tunggak Local (Vigna ungiculata L.) Terhadap Pemberian Pupuk. Skripsi. Universitas Pattimura. Ambon.

Martono, B. 2009. Keragaman genetik, heritabilitas dan korelasi antar karakter kuantitatif nilam (Pogostemon sp.) hasil fusi protoplas. Jurnal Littri 15: 9-15.

Ninik, S., Idris, dan M. Dahlan 2016. Kajian heritabilitas pada hasil persilangan antara kacang tunggak (Vigna unguiculata (L.) Walp.) varietas lokal NTB dengan kacang panjang (Vigna sesquipedalis (L.) Fruwirth). Crop Agro, Jurnal Ilmiah Budidaya 10: 56-64.

Ogle, W.L., W. Witcherm, and O. Barnett. 1987. Descriptors for the Southern peas of South Carolina Bulletin 659, South Carolina Agricultural Experiment Station, Clemson University, Clemson.

Patty. 2012. Uji Toleransi Beberapa Aksesi Kacang Tunggak Local (Vigna ungiculata (L) Walp.) Terhadap Cekaman Kekeringan. Skripsi. Universitas Pattimura. Ambon.

Rao, Ch.M., Y.K. Rao, and M. Reddy. 2006. Genetic variability and path analysis in mungbean. Legume Research 29: 216-218.
Sayekti, R.S., D. Prajitno, dan Toekidjo. 2012. Karakterisasi delapan aksesi kacang tunggak (Vigna unguiculate \{L.\} Walp) asal Daerah Istimewa Yogyakarta. Vegetalika 1: 110.

Syukur, M., S. Sujiprihati, R.Yunianti, dan D.A. Kusumah. 2011. Pendugaan ragam genetik dan heritabilitas karakter komponen hasil beberapa genotipe cabai. Jurnal Agrivigor 10: 148-156.

Trustinah. 2013. Plasma Nutfah Kacang Tunggak: Kacang Tunggak dan Potensinya di Lahan Kering Masam. Hal. 346-354, dalam Yudiwanti dkk. Prosiding Semnas PERIPI "Peran Sumber Daya Genetik dan Pemuliaan dalam Mewujudkan Kemandirian Industri Perbenihan Nasional".

Ujianto, L., Idris, dan U.M. Yakop. 2012. Kajian heritabilitas dan heterosis pada persilangan antara kacang tunggak dengan kacang panjang. Buletin Plasma Nutfah 18: 9-19. DOI: 10.21082/blpn.v18n1.2012.p9-17

Umaharan, P., R.P. Ariyanayagam, and S.Q. Haque, 1997. Genetik analysis of yield and is components in vegetable cowpea (Vigna unguiculata L. Walp). Eupgytica 96: 207-213. 